\title{
Reflections on Practice-Centred Curricula in Teaching Entrepreneurship in Malaysia
}

\author{
Alex Avramenko, \\ Abertay University, United Kingdom \\ Mehrunishah Begum, \\ Segi University Kota Damansara, Malaysia
}

\begin{abstract}
This paper discusses the challenges of entrepreneurship education in a regional Malaysian context and provides the design details of entrepreneurship modules providing a practical experience. It is argued that an active, experience-centred module delivery helps to revitalise student curiosity in entrepreneurial activities. The paper utilises the phenomenological approach to explore the contemporary challenges of entrepreneurship education and to gain a deeper insight into its contemporary complexity. The material for the phenomenological analysis is obtained by means of focus groups which are contrasted with the students' written reflections and staff observations on teaching and learning activities in entrepreneurship modules. The findings indicate that two months timescale for studying entrepreneurship is too short because of competing priorities within the programme of study and an eclectic essence of entrepreneurship. It was also found that students believe that being supported by tutors having practical experience is motivating and reassures them about further learning. The concerns about the applicability of Western concepts of entrepreneurship education to the Malaysian context were not corroborated. It has been argued that practice-centred learning opportunities are often associated with offcampus education and take place in the 'real world'. The suggested design for standalone entrepreneurship modules evidently ensures a rich experience for students and provides an effective springboard for developing entrepreneurial aspirations.
\end{abstract}

Keywords: Entrepreneurship Education, Practice-Centred Learning, Video Assessment, Lectorials, Practicals

Received: 1 Sept 2018

ISSN 2056-757X

Revised: 21 Sept 2018

Accepted: 5 Oct 2018

https://doi.org/10.18646/2056.53.18-010 


\section{Introduction}

Entrepreneurship education is seen as an important element of the Economic Transformation Programme within the scope of Malaysia's National Transformation Programme. The emphasis on the importance of entrepreneurship education is rooted in beliefs that entrepreneurship skills can be learned and may, over time, directly translate to an increase in the number of viable and sustainable business enterprises (Ahmad and Buchanan, 2015: 349). Furthermore, considering the unemployment level is relatively high among the graduates in Malaysia, lawmakers pin their hopes on enterprise creation since the continuous influx of fresh graduates into the labour market cannot be entirely absorbed by regular employment (Jaafar and Abdul-Aziz, 2008). This trend subsequently led to a scrutiny on the effectiveness of entrepreneurship education in Malaysia (Cheng et al., 2009).

This paper describes the use of practice-based entrepreneurship education in a private university in Malaysia. The challenges to entrepreneurship education will be explained, with an attention to the Malaysian context. This paper discusses the contextual difference between Western and Malaysian notions of entrepreneurship. The current practice in entrepreneurship education will be described, followed by an outline of an entrepreneurship module designed to enhance practice-centred learning. The approach utilises a combination of lectorials and practicals to be explained. The research methodology and results will be presented, and the paper ends with a conclusion and a summary of this paper.

\section{Entrepreneurship in Malaysia}

The development of entrepreneurship in Malaysia undergoes a series of transformation over the years. The indigenous people in Malaysia - the Malays - had a long history of economic achievement, dated back from the Melaka Sultanate (A.D. 1400-1500). For centuries, the Malay entrepreneurs were actively involved in trading and dealing with the foreign traders from many different countries, especially China and the Islamic world (Hamidon, 2014). However, the entrepreneurial tradition of the Malays fails to develop due to British colonial subjugation (Ariff and Abubakar, 2003; Hamidon, 2014). In modern times, the "immigrant communities" are often considered as the "cause of Malay deprivations" (Yao, 2003: 203). On a historical note, however, the Islamisation in Malaysia during the 15th century has also influenced the way Malays conduct businesses. For instance, the prohibition of interest on loan (riba) and profit sharing system (Mudarabah) propagated by Islam goes against the basic tenets of Capitalism. As Muslims, the Malays are prohibited from engaging in economic activities that are against Islamic philosophy, which includes producing, distributing and selling liquor and pork as well (Gümüsay, 2015). Additionally, the Malays' attitude towards investment differs from other ethnic groups in that they do not "prudently invest and reinvest their money for higher returns" (Hamidon, 2014: 69).

Over the years, the Malaysian government has introduced a series of initiatives, namely financial supports, tax incentives, business advisory assistance, as well as

International Journal of Management and Applied Research, 2018, Vol. 5, No. 3 
entrepreneurship courses. The introduction of New Economic Policy, National Higher Education Action Plan and Higher Education Entrepreneurship Development Policy represents some of the Malaysia government initiatives in promoting entrepreneurship.

Nevertheless, statistics show that the number of entrepreneurs is quite low (GEM, 2016; Ministry of Higher Education, 2016). In reference to Ministry of Higher Education (2016a), only $6.8 \%$ of the total graduates $(283,672)$ in 2016 are selfemployed after graduation. This is a quite low number of new business creation among the graduates, especially considering the fact that 22.7 percent of the graduates were unemployed six months after graduation in that year (Ministry of Higher Education, 2016b). Unsurprisingly, the low number of new venture creation is accompanied by a low interest in creating a new business among the university students (Robuan et al., 2017). According to GEM (2016), the rate of entrepreneurial intention in Malaysia is significantly lower than the global average of 22.32 percent, with just 4.86 percent.

There are a number possible reasons to explain a comparatively low level of entrepreneurial activities in Malaysia, including lack of financial resources (Robuan et al., 2017), lack of business background (Hamidon, 2014), poor entrepreneurial readiness (Othman et al., 2012), lack of knowledge and experience (Robuan et al., 2017), risk-avoidance behaviour (Hamidon, 2014), lack of business networking and connections (Hamidon, 2014), negative attitude towards business failure (Ariff and Abubakar, 2003; GEM, 2016; Hamidon, 2014), and Malaysian cultural specifies (OECD, 2011: 171). A closer examination on these factors suggests that some of these problems are attitudinal, and entrepreneurship education could help to change the perception towards entrepreneurship.

\section{Entrepreneurship Education in Malaysia}

Malaysian higher education is represented by at least one public university in each of its 13 states, as well as in three federal territories on the island of Borneo. Altogether, this adds up to 20 public universities which were mostly established in the 1990s and receiving more than $60 \%$ of their annual funding from the government. The number of private universities in Malaysia has been increasing gradually; at the time of writing, there are 46 private universities with most of the universities offering entrepreneurship programmes. Ahmad and Buchanan (2015) indicate that all public and some private universities offer basic introduction to entrepreneurship as a general subject or as part of the business management curricula, with some of these universities claiming to be providing designated entrepreneurship education at both undergraduate and postgraduate levels.

In 2007, the Ministry of Higher Education (MoHE) made it mandatory for all students in public universities to take entrepreneurship course, with the main aim of fostering entrepreneurs among graduates (Ahmad and Buchanan, 2015; Cheng et al., 2009; Robuan et al., 2017). Private universities have followed this lead, as the pursuit of wide-spread entrepreneurship education has been reinforced by the Ministry of Entrepreneurship and Cooperative Development, and the Ministry of Higher Education. Arguably, however, the compulsory nature of taking entrepreneurship

International Journal of Management and Applied Research, 2018, Vol. 5, No. 3 
courses reduces the interests among students (OECD, 2011: 170). Robuan et al. (2017) reported that the compulsory entrepreneurship course in Malaysia has not been able to raise awareness and promote interest to create a new venture among the first year students. Robuan et al. (2017) noticed that many graduates do not consider entrepreneurship as a preferred career option after graduation, which is consistent with other research which found that entrepreneurship is not the first career choice for graduates (Cheng et al., 2009; Hamidon, 2014; Mohamad et al., 2015).

Although entrepreneurship education is very much present in Malaysian universities, and its role is growing, questions have been raised regarding the effectiveness of entrepreneurship education in promoting entrepreneurial activities in Malaysia (Cheng et al., 2009; Hamidon, 2014; Robuan et al., 2017). The traditional teaching methods used in delivering entrepreneurship courses are being criticised as "fail to support creativity" (OECD, 2011: 170) and "too theoretical to grasp" (Ahmad et al. 2014: 404), leaving limited scope for practice and application (OECD, 2011: 169). Reportedly, some students felt that the curriculum offered is a bit too outdated to be relevant and fail to develop entrepreneurial attitude (Ahmad et al. 2014: 404). Similarly, Cheng et al. (2009) found that the content delivery of the entrepreneurship education does not meet with students' skill expectations. Additionally, research capacity is also being undermined due to shortage of faculty members with doctoral qualifications and a lack of research funding (Ahmad and Buchanan, 2015).

The establishment of the National Entrepreneurship Institute (INSKEN) in 2005 was supposed to revitalise the landscape of entrepreneurship education (Szopa, 2015). One of the initiatives supported by INSKEN is the Basic Student Entrepreneurial Programme (BSEP), targeting final year students in higher education institutions who are interested in pursuing business opportunities after graduation. Through this programme, participants are being exposed to a number of subjects, namely opportunity recognition, marketing, entrepreneurial simulations, as well as the characteristics of successful entrepreneurs in order to motivate graduates to enter the realm of business (Mohamed et al., 2012).

The aim of this paper is to support the INSKEN mission (Institut Keusahawanan Negara, 2016) and other country-wide initiatives, such as National Higher Education Action Plan (Mohamad et al., 2015) and Higher Education Entrepreneurship Development Policy (Ahmad et al., 2014), with a practice-based pedagogy serving as an effective means to help universities with curriculum reforms and enable students to connect with entrepreneurship and the entrepreneurial way of life, as well as equipping them with entrepreneurial skills useful in the exploration of their current and future aspirations.

\section{Current Practice of Entrepreneurship Education}

While the objectives of entrepreneurship education are relatively clear - developing an understanding of entrepreneurship by students, learning to act in an entrepreneurial way and gaining knowledge of becoming an entrepreneur (Heinonen and Poikkijoki, 2006), attaining this is not without certain challenges. One of the most cited challenges is 'the appropriateness of curricula and training programmes for

International Journal of Management and Applied Research, 2018, Vol. 5, No. 3 
preparation for learning in the outside world' (Garavan and O'Cinneide, 1994: 9). This message is still compelling today because of the rapid expansion of the knowledge base in entrepreneurship. Another aspect of appropriateness is the continuously changing economic and social conditions of the new millennium (Rae, 2010). These contemporary changes have an impact on entrepreneurship development, which in turn calls for transformative changes in educating for entrepreneurship.

One challenge permeating entrepreneurship education is the need to incorporate "learning by doing" (Gibb, 2011; Pittaway and Cope, 2007) to enable learning "for" rather than "about" entrepreneurship (Duval-Couetil, 2013). While the argument in favour of practice-centred learning is persuasive, guidance on organising practical entrepreneurial activities (to develop skills and behaviours) is limited. Bliemel (2014a: 240) argues that "the panacea for university-based EE lies in experiential learning opportunities, which ironically often means learning off-campus and in the 'real-world"'. Hägg and Kurczewska (2016: 702) add to this discussion the argument that experience-centred element in learning is extensively used as a foundation for learning entrepreneurship but without a 'theoretical and philosophical understanding of the concept of experience'.

Another far-reaching challenge that needs to be mentioned is the applicability of Western concepts of entrepreneurship education in the Malaysian context. It is not only the economic underpinning of education resting on the paradigm of deregulated market economic growth; the main concern is about the relevance of Western cultural values to underpin the adaptability or redesign of pedagogy (Rae, 2010). As Robuan et al. (2017: 105) put it: "Implementation of such a programme in a very different cultural environment may take a number of elements for granted that are lacking in Malaysia". This view is echoed by such scholars as Basden (2011), who uses Dooyeweerd's philosophy to reveal the inescapable religious presuppositions underlying everyday thinking and theoretical activity, as well as Gümüsay (2015), who endeavours to explore entrepreneurship from an Islamic perspective. Empirical studies indicate that religion has a shaping effect on work in contemporary settings (Ababneh and Avramenko, 2016); Islamic values are being practiced, albeit to a limited extent.

With such an intricate view of contemporary entrepreneurship education and the role of experience and religion within it, the key concepts and intentions in this area should be operationalised. While there are different routes to organising practicecentred learning, (Bliemel, 2014b) suggests it as 'learning by working on the student's own business ideas, supported by exposure to guest speakers and guidance by mentors'. The diffusion of Islamic values into the educational process should be explicitly addressed.

The paper offers operational details of a particular mode of practice-centred learning, particularly suited to standalone entrepreneurship modules within the scope of business and management programmes. The emphasis is on students gaining practical experience while developing and communicating their own business ideas.

International Journal of Management and Applied Research, 2018, Vol. 5, No. 3 


\section{Design of Learning Sessions}

The main emphasis of the proposed design is on supporting a student's learning on campus, accentuating the practical activities in line with constructivist pedagogic beliefs (Avramenko, 2012). This design was implemented at different undergraduate levels $\left(2^{\text {nd }}, 3^{\text {rd }}\right.$ and $\left.4^{\text {th }}\right)$ of standalone entrepreneurship modules, i.e. delivered within the scope of various business and management programmes of study. The class size varied between 25 to 85 students with students working in self-arranged groups.

These entrepreneurship modules have drawn on the model of entrepreneurial process advocated by Timmons as well as the work of Neck and Greene (2011). Timmons model consists of three key elements in entrepreneurship: opportunity, resources, and team. The entrepreneurial process, according to Timmons (1999), is driven by opportunities, where entrepreneurs identify potential market and assess market attractiveness before building an effective team and organising resources. Based on the Timmons conception, our proposed module design weights on team-building, resourcefulness, and opportunity recognition, where each topic builds upon the previous one. However, one major problem for structuring module in such a linear way is that students may mistake entrepreneurship as a linear process (Honig, 2004). For that reason, our framework also incorporates elements of the "cognition world" model (Neck and Greene, 2011: 60), recognising both functions: thinking and doing entrepreneurially. This framework (Figure 1) has been used for guiding the curriculum development.

Figure 1 Process Model

Taking Action

Do

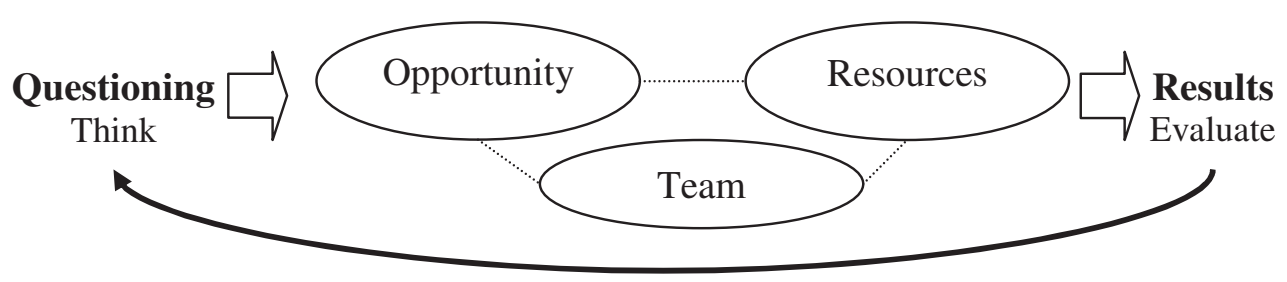

\section{Reflecting}

Think again

Adapted from: Timmons, 1999

Each entrepreneurship module was delivered on a weekly basis and consisted of two types of learning sessions: lectorials and practicals. Lectorial sessions were a modification of a traditional lecture with elements of subject-driven staff and student interactions, where the students were working in their assessment-related groups to facilitate a focused theory application of key concepts. The interactive elements of a lectorial embrace but are not limited to discussion based quizzes (Duval-Couetil, 2013; Hynes, 1996), short problem-solving scenarios (Tan and Ng, 2006), mini competitions (Thompson, 2013), probing entrepreneurs (Neck and Greene, 2011; Shepherd, 2004; Solomon, 2007) and evaluations of presented opportunities (Gielnik

International Journal of Management and Applied Research, 2018, Vol. 5, No. 3 
et al., 2015; Hynes, 1996; Neck and Greene, 2011). The transition from lectures to lectorials is intended to stimulate student engagement with the subject and to encourage activity-based knowledge discovery.

Practical sessions represent an opportunity for students to put their learning into practice guided by assessment-related tasks and to receive continuous formative feedback. The assessment strategy itself has been changed from the traditional oral presentation (Cheng et al., 2009; Hynes, 1996) to video or multimedia assessment where the students were required to create video footage presenting outcomes of opportunity recognition and/or value propositions of their ideas. Creating video material in order to communicate complex ideas and the solutions developed to business and societal problems represents a new skill category. Despite the younger generation is more technological savvy, this does not necessarily mean that these digital natives have the skills to create a persuasive infomercial or multimedia content that will convey product information and engage the consumer at the same time (Matveev and Mitler, 2010). Student-produced video is increasingly recognised as a viable assessment since it provides an authentic real-world exposure (Schultz and Quinn, 2014). The process of creating a video undergoes a series of stages: datagathering, writing, editing, and presenting. The preparation for an attractive value propositions or infomercial, on the other hand, requires greater emphasis on creativity and problem-solving skills (Matveev and Mitler, 2010). Practicals provide an opportunity to develop such skills, while addressing the potential technical issues of video creation, upload, download and distribution in a practical way. The argument for video assessment is strengthen by the fact that video is an effective tool to communicate idea and persuade potential investors. Kickstarter, a popular crowdfunding site, reveals that projects with videos always receive greater attention and higher success rate than those without (O'Connell and Kurtz, 2012).

The preparation of business plan is still included as a part of assessment because it helps to develop secondary research skill (Neck and Greene, 2011) as well as demonstrate the ability of the students to integrate learning material across different business subjects (Honig, 2004). Overall, the business plan is being superseded by feasibility studies to create a blueprint for a new idea or venture grounded in real data and verifiable methodology (Cheng et al., 2009; Honig, 2004; Neck and Greene, 2011; Solomon, 2007; Timmons, 1999).

In the end of the course, the students are required to write a reflective report. As Neck and Greene (2011) pointed out, reflective practice is critical to the overall learning experience as it promotes deeper learning and questioning underlying assumptions. Given the nature of entrepreneurship as a continuous cycle of thinking and doing, reflection allows one to rethink and make sense of past experience. Reflecting on the "what works" and "what doesn't work" (Rae, 2003: 544) is helpful in evaluating the effectiveness of the strategies used in the entrepreneurial process.

The last, but not least, aspect of these new experience-centred style entrepreneurship modules is the use of technology. It combines the use of the institutional Virtual Learning Environment, to provide students with an online learning space for sharing (file repository) and collaboration (blogging or wiki), with a number of external

International Journal of Management and Applied Research, 2018, Vol. 5, No. 3 
resources. For instance, Google Street View enables students to explore the intended locality for the new venture; the local city council website provides information about pertinent licensing and permits; real estate assessors associations supply information about commercial leases. The purpose of asking students to gather factual information -- rather than giving fictional information -- is to allow students to have an authentic real world experience so that they could jump start their ventures after completion of their study.

This pedagogy of synthesising actual industry information with entrepreneurship theory underpinned by creation of video content and feasibility assessment puts students in the position of novice entrepreneurs. Along the way, students develop their skills in opportunity recognition, market assessment, and business ideas communication. The students also need to make sense of what they learnt from the module and apply it into practice.

Additionally, students aiming at or having created their own enterprises are also supported by entrepreneurs in residence (George et al, 2010), who are the members of staff with entrepreneurial experience. Further support for students interested in taking their ideas forward can be organised in the form of a business incubator (Manolova et al., 2008) or accelerators (Adomdza, 2016; Thompson, 2013) to facilitate start-ups or use a more flexible form of enterprise clinic. The latter has been in running in parallel with entrepreneurship modules and has established itself as a knowledge hub (as opposed to a source of advice) in dealing with complex, knowledge intensive issues providing an opportunity for contextual problem-solving, addressing intellectual property challenges, and issues of organic growth or troubleshooting in newly established ventures.

\section{Research Settings}

This research was conducted within the scope of a collaboration between academic staff at the School of Business of SEGi University Group (Systematic Educational Group International, 2016), one of the largest private higher education institutions in Malaysia, with Abertay University in Scotland. The collaborative effort was supported by the EU staff mobility exchange programme (Eramus Plus, 2016), enabling enterprise educators to actively participate in the delivery and assessment of general, specialised and extracurricular entrepreneurship courses in a partner institution.

The methodological base of this research is grounded in phenomenological enquiry (Cope, 2005), aiming to get a deeper insight into the complexity of contemporary entrepreneurship education and the challenges associated with it for key stakeholder categories: tutors and students. The analysis of the collected material was guided by the challenges in teaching entrepreneurship and ways of overcoming those.

The students' views were collected through focus groups (6) and written reflections (264) upon completion of entrepreneurship modules. The views were analysed following the principles of hermeneutic phenomenological enquiry.

International Journal of Management and Applied Research, 2018, Vol. 5, No. 3 


\section{Results}

The results section presents student and staff views on the challenges of entrepreneurship education, and followed by a review of the effectiveness of the entrepreneurship module via the prism of student experience.

\subsection{Challenges in Entrepreneurship Education: Perception of Students}

The students' views are presented, according to the spirit of hermeneutic phenomenological enquiry, in themes which emerged during data analysis whilst utilising the students' expressions verbatim.

\section{Theme: reasons for appreciation of entrepreneurship education}

It was explicitly indicated that entrepreneurship education helps to realise the need for a mindset which appreciates the possibility of creating one's own future by acquiring 'knowledge and skills necessary for creating new business ideas'. It would also allow learners 'to transform dream into doable business with entrepreneurial knowledge'. Entrepreneurship 'opens one's mind to a broader perspective' and enabled the student 'to identify opportunity that exists in one's surrounding'. Entrepreneurship education 'will not let the dream remain as a dream' and will help 'fulfill our dream to open up a business'. It provides an opportunity 'to create a business plan for a business of choice'. At the very least after a course in entrepreneurship students will know what it takes 'to be a successful entrepreneur' and to 'understand what is needed to start- up a business'.

\section{Theme: further learning is required for entrepreneurship}

The need to understand how a particular venture should be functioning emerged in various connotations. This indicates the preoccupation of students with the enterprise side of entrepreneurship. Students in particular specified the need to have a contextual knowledge of industry working and analysis, networking opportunities and tactics. The other learning needs included understanding 'terms and conditions in venturing into this sector', choice of a start-up model, legal aspects and identification of relevant funding opportunities. A specific emphasis was on identification of key influences on 'sustainability of the enterprise'.

\section{Theme: personal challenges in studying entrepreneurship}

Despite of the potential sensitivity of this theme students were surprisingly upfront about the challenges and/or obstacles they experienced in their learning. This fact can be rationalised by the essence of the focus group; that it is a discussion with peers as opposed to the question-answer mode of interviews. Moreover, information provided in written reflections was quite explicit and revealing about various factors impeding students' learning of entrepreneurship. These findings are presented in a prioritised manner, from the most frequently mentioned to the least important.

\section{Theme: timescale for studying entrepreneurship}

It was overtly stated that "three months to study entrepreneurship module is not enough'. There are two main modes of studying entrepreneurship: in a curricular and an extracurricular mode. Using the former an entrepreneurship module would be studied for three months, while an extracurricular method can be spread over a longer period of time. However, even in the latter case there is a pressure of competing

International Journal of Management and Applied Research, 2018, Vol. 5, No. 3 
priorities, that is; 'too many subjects taken at the same time'. The main reason being given is that studying entrepreneurship is not only absorbing the subject knowledge of the discipline. It requires changes in the mindset together with practical experience of being a resource coordinator and of risk appreciation.

This main argument, shared unanimously, can be summarised by saying that studying entrepreneurship requires practice of its key tenets. It was pointed out that creating a business plan is not sufficient as the key stage - implementation and/or evaluation would require an experience-centred aspect to complete the learning circle. This argument is valid not only in the context of learning entrepreneurship but throughout the entire domain of business and management studies. It's not easy to provide the experience of establishing and/or running a business unit in a classroom. It is a universal challenge for educators across the globe.

\section{Theme: being supported by tutors with experience of entrepreneurship}

It was acknowledged that being exposed to different teaching methods is not as important for students as the fact that the tutors must have practical experience of entrepreneurship. Lack of such experience was de-motivating and discouraged personal enquiries and further exploration of the subject, especially in the case of dealing with 'fear of failing in entrepreneurial activities'. Without guidance from knowledgeable and practised staff, it was difficult to overcome anxiety about the unknown even if the theory maintains that 'an initial failure leads a step closer towards success'. It was noted that staff previously involved in enterprising activities were more helpful and trustworthy as they were better able to explain the multidisciplinary essence of entrepreneurship.

\section{Theme: entrepreneurship and new venture creation}

Students seem to equate entrepreneurship with new venture creation, while losing focus on innovation. It was repeatedly indicated that commercialising an idea or opportunity in a different context is allied with the meaning of entrepreneurship. The opportunities mentioned reflected ideas about products or services absent in particular localities.

\subsection{Challenges in Entrepreneurship Education: Perceptions of Staff}

The members of staff participating were tutors teaching entrepreneurship courses on a regular basis. The staff views were expressed in focus groups and grouped in themes during the analysis stage. Tutors were encouraged to share their regular staff teaching reflections. Overall, discussions were centred on perceived challenges in teaching and learning entrepreneurship and how those challenges can be overcome. The outcomes of the discussions are presented in the emerged themes, utilising original expressions verbatim. All emerged themes resonate well with students views.

\section{Theme: entrepreneurship courses require more time}

Teaching entrepreneurship is challenging as it is rather eclectic in its content; 'too much to cover in a short period' typically of three months. Moreover, learning entrepreneurship goes beyond expanding the individual's knowledge base, it requires a 'change in mindset' in order to develop entrepreneurial creativity and recognition of

International Journal of Management and Applied Research, 2018, Vol. 5, No. 3 
opportunities. In contrast, learning in other management disciplines is often gradual and spans the programme of study.

Theme: the challenge of providing practical experience of entrepreneurship Ensuring the 'practice of entrepreneurship' was repeatedly named as a key factor in learning or mastering it. There is a need to distinguish between the teaching and the learning of enterprise and entrepreneurship. The latter refers to the application of enterprise skills, comprising ideation and problem-solving grounded in communication and practical action. Hence, enterprise skills need to be initially developed to permit effective learning of entrepreneurship. This logical sequence represents a challenge in terms of curriculum development, especially in the case of standalone entrepreneurship modules.

\section{Theme: teaching non-business students}

Two main challenges have been identified under this theme. The first one is about associating entrepreneurship and business in general, with a "need for large amount of investment or capital'. Having capital is perceived by students as being a prerequisite or starting point for thinking about, recognising and exploring opportunities. The second challenge relates to overcoming 'fear of complexity' associated with business activities by non-business students. Hence, the student's thinking is in line with the statement 'why bother to be entrepreneurial' - it's for people having an appropriate background.

\section{Theme: teaching to be creative and innovative}

Teaching students to be creative and innovative is a challenge within any discipline, but it was argued by tutors that within the scope of a standalone entrepreneurship module it is close to impossible without compromising the depth of coverage. Being creative is conceptualised as a skill and like any other skill it requires time and a favourable environment in order to be developed to the level of generating viable ideas. Being innovative is understood as the next level - of implementing by means of new methods or techniques. Developing both skills requires time and contextually innovative methods to enable the cultivation of the student's creative potential.

\subsection{Post Module Evaluation}

The views of students on entrepreneurship modules aiming to provide them with opportunities for active and real life centred experience have been identified through focus groups and written reflections. The views are presented in the form of reflective comments verbatim, followed by the staff comments.

It was made explicit that learning via continuous practice helped to demystify the meaning of entrepreneurship, the role of the entrepreneur and various aspects of enterprise:

'Before I started this module, the idea of entrepreneurship seemed very distant to me...This module has not just showed me the complexity of being an entrepreneur, but taught me how I can apply my creativity to become a better entrepreneur';

'In the process I have experienced the process of creating estimates, analysing markets and competition, and analysing the project from a financial

International Journal of Management and Applied Research, 2018, Vol. 5, No. 3 
standpoint... I feel much more confident in my abilities after completing this module. It has broadened my knowledge and changed the ways I approach ideas';

'I had the opportunity to learn a new and more complete perspective [on entrepreneurship]... I developed a sensibility towards the different dimensions of enterprise feasibility: I stopped reflecting upon the financial point of view only, and I embraced the complexity of what concerns the operational feasibility, the interaction with the market, and the intrinsic value of the product or service itself';

'learning in practice how difficult it can be to compete and different types of competition provided me with experience and knowledge of industry that I never thought be possible until I establish my company... I'm confident to tackle any issues with competition in an over-saturated market in more creative ways'.

Staff views about the new, practice-based mode of delivering entrepreneurship modules are appreciative. It is possible to notice the gradual development of learning as students' enquiries get more mature as the module progresses. On the other hand, the preparation needed for interactive lectorials has increased dramatically due to the increased number of weekly activities. Similarly, assessment of video material prepared by students is more time consuming compared to traditional pitches. Finally, the practice based nature of these module means that providing continuous formative feedback requires a new set of skills in analysing and responding to student's queries. The latter would not be possible without the prior entrepreneurial experience of staff.

Altogether the practice based mode of the entrepreneurship module's delivery enables students not just to put their learning into practice but to operationalise the key concepts of entrepreneurship. The use of video in assessment helps students to be more reflective about the outcomes of their own creation.

\section{Discussion}

The established literature on the relevance of entrepreneurship courses emphasises the appropriateness of the content (Garavan and O'Cinneide, 1994; Rae, 2010) and teaching methods (Gibb, 2011) to the realities of the new millennium. It is recognised that practice-centred philosophy may provide a much needed pathway to organise contemporary entrepreneurship teaching and learning (Duval-Couetil, 2013; Gibb, 2011; Pittaway and Cope, 2005).

This study indicates that the appropriateness of the content can be optimised by maintaining a close focus on the national and local context. Approached in this way courses will be relevant to the students and, combined with a contextual synthesis of actual industry information with a knowledge base of entrepreneurship theory, would provide a sound basis for the formation of entrepreneurial mindset and skills.

This study also reveals that the design of entrepreneurship modules can use a number of practice-centred teaching interventions enabling effective entrepreneurial skills development. It would allow for more flexible module delivery and incorporate the

International Journal of Management and Applied Research, 2018, Vol. 5, No. 3 
actual interest of learners. The recent inclusion of video material (e.g. value proposition) creation and dissemination would not only enabled the showcasing of the quality and maturity of the student's work but also ensures the development of contemporary skills, such as video content's editing and copyrighting as well as using video as means of communicate compound ideas.

The challenge of the applicability of Western principles to entrepreneurship education in a country where Islam is the dominant religion has not been theorised in full. However according to Gümüsay (2015), the role of Islam in entrepreneurship is based on an interconnection between the textual sources and contextual setting, not on the ways entrepreneurship is taught and learnt. This claim is corroborated by the findings of this study and no concerns about practicalities of practice-centred learning were expressed by participating students or staff. Instead, the findings indicate that students are sensitive to the fact that tutors on entrepreneurship modules should have practical entrepreneurial experience in order to be motivating and persuasive on the grounds of the synthesis of theoretical knowledge and own practice. This reportedly would help learners in dealing with the fear of failure in entrepreneurial endeavours.

The argument that staff previously involved in enterprising activities was more trustworthy and better at explaining the multidisciplinary essence of entrepreneurship is not new. Kuratko (2005) maintains that the lessons learned from practised entrepreneurs can 'make a difference' for students in enhancing their entrepreneurial capacity. It is gradually becoming a norm to utilise the help of 'entrepreneurs in residence' (George et al, 2010), who are also members of teaching staff. The exposure of students to entrepreneurship theory's practitioners can take many forms, but in essence it would enhance student's educational experience and ensures relationships and interactions between students and entrepreneurs (Pittaway and Cope, 2007).

\section{Conclusions}

This paper aims to contribute to the development of practice-based entrepreneurship modules to be used by Malaysian educators and to support government initiatives aiming to equip students with entrepreneurial skills adequate for exploration of immediate and future aspirations.

The principles of designing entrepreneurship modules guided by practice-centred pedagogic beliefs have been outlined and tested by the actual design and delivery of such modules in collaborating universities. The outcomes of this effort indicate that active, practice-centred learning is appreciated by students. Moreover, it has greater impact in the context of skills development and encourages further knowledge discovery.

On the operational side, practice-based entrepreneurship modules do not require considerable financial investment, except ensuring that entrepreneurship modules are supported either by entrepreneurs in residence or by members of staff with entrepreneurial experience, who are enthusiastic about active exploratory learning of entrepreneurship. The use of video in the assessment of entrepreneurship modules while requiring new skills for developing and assessing video material, at the same

International Journal of Management and Applied Research, 2018, Vol. 5, No. 3 
time helps to demystify entrepreneurial activities and illustrate the value creation potential of new ideas.

The findings of this study resonate with research into entrepreneurship education. Staff and students agree that getting into the entrepreneurial mindset would require more time than allowed by the duration of a traditional entrepreneurship module following the conventional modular structure of a programme of study. The practicecentred elements of engagement with entrepreneurs, ongoing entrepreneurial problemsolving and assessment activities, such as preparing an enticing video of the new product or service, conducting a locality and/or industry based feasibility study to gauge prospective customer numbers, are grounded in the local context.

The further research is envisaged as providing additional generalisable evidence of the effectiveness of the proposed module design accompanied by robust evidence of student performance. The suggested combination of the new entrepreneurship module's design together with the supporting infrastructure to stimulate start-ups and their growth should be tested in more than one university to enable more grounded conclusions about its value.

\section{References}

1. Ababneh, H. and Avramenko, A. (2016), "Impact of Islamic values on HRM practices: an empirical study of Jordanian universities", International Journal of Business Excellence, vol. 9, No. 4, pp. 1-16 https://doi.org/10.1504/IJBEX.2016.077625

2. Ahmad, S. Z., and Buchanan, R. F. (2015), "Entrepreneurship education in Malaysian universities", Tertiary Education \& Management, Vol. 21, No. 4, pp. 349-366. https://doi.org/10.1080/13583883.2015.1106577

3. Ahmad, S. Z., Ismail, M. Z., and Buchanan, F. R. (2014), "Examining the entrepreneurship curriculum in Malaysian polytechnics", International Journal of Management Education, Vol. 12, No. 3, pp. 397-406.

https://doi.org/10.1016/j.ijme.2014.06.004

4. Adomdza, G. K. (2016), "Choosing Between a Student-Run and Professionally Managed Venture Accelerator", Entrepreneurship: Theory \& Practice, Vol. 40, No. 4, pp. 943-956. https://doi.org/10.1111\%2Fetap.12145

5. Ariff, M. and Abubakar, S.Y. (2003), Strengthening entrepreneurship in Malaysia, Washington DC: The Maureen and Mike Mansfield Foundation, [Online] available from: http://www.mansfieldfdn.org/backup/programs/program_pdfs/ent malaysia.pdf [accessed on 22 January 2018]

6. Avramenko, A. (2012), "Enhancing students' employability through business simulation", Education + Training, Vol. 54, No. 5, pp. 355 - 367. https://doi.org/10.1108/00400911211244669

International Journal of Management and Applied Research, 2018, Vol. 5, No. 3 
7. Basden, A. (2011), “A Presentation of Herman Dooyeweerd's Aspects of Temporal Reality", International Journal of Multi-aspectual Practice, Vol. 1, No. 1, pp. 1-28.

8. Bliemel, M. J. (2014a), "Getting Entrepreneurship Education Out of the Classroom and into Students' Heads", Entrepreneurship Research Journal, Vol. 4, No. 2, pp. 237-260. https://doi.org/10.1515/erj-2013-0053

9. Bliemel, M. J. (2014b), "Lessons learned from an inside-out flip in entrepreneurship education", Small Enterprise Research, Vol. 21, No. 1, pp. 117 128. https://doi.org/10.1080/13215906.2014.11082080

10. Cheng, M. Y.; Chan W. S. and Mahmood, A. (2009), "The effectiveness of entrepreneurship education in Malaysia", Education + Training, Vol. 51, No. 7, pp. 555 - 566. https://doi.org/10.1108/00400910910992754

11. Cope, J. (2005), "Researching Entrepreneurship through Phenomenological Inquiry Philosophical and Methodological Issues", International Small Business Journal, Vol. 23, No. 2, pp. 163-189. https://doi.org/10.1177\%2F0266242605050511

12. Duval-Couetil, N. (2013), “Assessing the Impact of Entrepreneurship Education Programs: Challenges and Approaches", Journal Of Small Business Management, Vol. 51, No. 3, pp. 394-409. https://doi.org/10.1111/jsbm.12024

13. Eramus Plus (2016), Apply for higher education student and staff mobility funding, [Online] Available from: https://www.erasmusplus.org.uk/apply-for-highereducation-student-and-staff-mobility-funding [Accessed 26 August 2016].

14. Garavan, T. N. and O'Cinneide, B. (1994), "Entrepreneurship Education and Training Programmes: A Review and Evaluation". Journal of European Industrial Training, Vol. 18, No. 8, pp. 3 - 12. https://doi.org/10.1108/03090599410068024

15. George, M.; Gordon, I. and Hamilton, E. (2010), "What is (the point of) an entrepreneur in residence", Industry \& Higher Education, Vol. 24, No. 6, pp. 495503. https://doi.org/10.5367\%2Fihe.2010.0015

16. Gibb, A. (2011), "Concepts into practice: Meeting the challenge of development of entrepreneurship educators around an innovative paradigm: The case of the International Entrepreneurship Educators' Programme (IEEP)", International Journal Of Entrepreneurial Behaviour And Research, Vol. 17, No. 2, pp. 146-165. https://doi.org/10.1108/13552551111114914

17. Gielnik, M.; Frese, M.; Kahara-Kawuki, A.; Wasswa Katono, I.; Kyejjusa, S.; Ngoma, M.; Munene, J.; Namatovu-Dawa, R.; Nansubuga, F.; Orobia, L.; Oyugi, J.; Sejjaaka, S.; Sserwanga, A.; Walter, T.; Bischoff, K. and Dlugosch, T. (2015). "Action and Action-Regulation in Entrepreneurship: Evaluating a Student Training for Promoting Entrepreneurship", Academy Of Management Learning \& Education, Vol. 14, No. 1, pp. 69-94. https://doi.org/10.5465/amle.2012.0107

International Journal of Management and Applied Research, 2018, Vol. 5, No. 3 
18. Global Entrepreneurship Monitor (GEM) (2016), Entrepreneurial Behaviour and Attitudes in Malaysia, [Online] available from: http://www.gemconsortium.org/country-profile/86 [accessed on 22 January 2018].

19. Gümüsay, A. A. (2015), "Entrepreneurship from an Islamic perspective", Journal Of Business Ethics, Vol. 130, No. 1, pp. 199-208. https://doi.org/10.1007/s10551014-2223-7

20. Hägg, G. and Kurczewska, A. (2016), "Connecting the dots - A discussion on key concepts in contemporary entrepreneurship education", Education + Training, Vol. 58, No. 7/8, pp. 700-714. https://doi.org/10.1108/ET-12-2015-0115

21. Hamidon, S. (2014), The development of Malay Entrepreneurship in Malaysia, Kuala Lumpur: Institut Terjemahan \& Buku Malaysia Berhad.

22. Heinonen, J. and Poikkijoki, S. (2006), "An entrepreneurial-directed approach to entrepreneurship education: mission impossible?", Journal of Management Development, Vol. 25, No. 1, pp. $80-$ 94. https://doi.org/10.1108/02621710610637981

23. Honig, B. (2004), "Entrepreneurship Education: Toward a Model of ContingencyBased Business Planning", Academy of Management Learning and Education, Vol. 3, No. 3, pp. 258-273. https://doi.org/10.5465/amle.2004.14242112

24. Hynes, B. (1996), "Entrepreneurship education and training - introducing entrepreneurship into non-business disciplines", Journal of European Industrial Training, Vol. 20, No. 8, pp. $10-17$. https://doi.org/10.1108/03090599610128836

25. Jaafar, M. and Abdul-Aziz, A. R. (2008), "Entrepreneurship education in developing country: Exploration on its necessity in the construction programme", Journal of Engineering, Design and Technology, Vol. 6, No. 2, pp. 178 189. https://doi.org/10.1108/17260530810891306

26. Krueger, RA and Casey MA (2015). Focus groups: A practical guide for applied research, $5^{\text {th }}$ ed., USA: Sage Publications.

27. Kuratko, D. F. (2005), "The Emergence of Entrepreneurship Education: Development, Trends, and Challenges", Entrepreneurship: Theory \& Practice, Vol. 29, No. 5, pp. 577-597. https://doi.org/10.1111/j.1540-6520.2005.00099.x

28. Matveev, A. V. and Milter, R. G. (2010), "An implementation of active learning: assessing the effectiveness of the team infomercial assignment", Innovations In Education \& Teaching International, Vol. 47, No. 2, pp. 201-213. https://doi.org/10.1080/14703291003718935

29. Ministry of Higher Education (2016a), Employment by Sector, [Online] available from: http://graduan.mohe.gov.my/skpgreport/Dashboard/TrendSektorPekerjaan.aspx [accessed on 23 January 2018].

International Journal of Management and Applied Research, 2018, Vol. 5, No. 3 
30. Ministry of Higher Education (2016b), Employment Rate, [Online] available from: http://graduan.mohe.gov.my/skpg-report/Dashboard/TrendStatusPekerjaan.aspx [accessed on 23 January 2018].

31. Mohamad, N., Lim, H., Yusof, N., and Soon, J. (2015), "Estimating the Effect of Entrepreneur Education on Graduates' Intention to Be Entrepreneurs", Education \& Training, Vol. 57, No. 8/9, pp. 874-890. https://doi.org/10.1108/ET-03-20140030

32. Moon, J.A. (1999), Reflection in Learning \& Professional Development: Theory \& Practice, London: Kogan Page.

33. O'Connell, M. and Kurtz, (2012), How To Make an Awesome Video, [Online] available from: https://www.kickstarter.com/blog/how-to-make-an-awesomevideo (Accessed on 23 January 2018).

34. Organisation for Economic Co-operation and Development (OECD) (2011), Higher Education in Regional and City Development Higher Education in Regional and City Development: State of Penang, Malaysia, OECD Publishing.

35. Institut Keusahawanan Negara (2016), INSKEN's Entrepreneur-Centric Programmes, [Online] available from: http://www.insken.gov.my/index.php/my/arkib-pengumuman/606-insken-sentrepreneur-centric-programmes-for-2016 (Accessed 23 June 2016).

36. Quality Assurance Agency for Higher Education (2010), Audit of overseas provision: The University of Abertay Dundee and Systematic Educational Group International (SEGi) Malaysia, [Online] available from: http://www.qaa.ac.uk/en/Publications/Documents/University-of-Abertay-DundeeSystematic-Educational-Group-International-SEGI-Malaysia-AOP-10.pdf (Accessed 11.07.2016)

37. Pittaway, L. and Cope, J. (2007), "Entrepreneurship Education A Systematic Review of the Evidence", International Small Business Journal, Vol. 25, No. 5, pp. 479-510. https://doi.org/10.1177\%2F0266242607080656

38. Rae, D. (2003), "Opportunity centred learning: an innovation in enterprise education?", Education + Training, Vol. 45, No. 8, pp. 542-549. https://doi.org/10.1108/00400910310508928

39. Rae, D. (2010), "Universities and enterprise education: responding to the challenges of the new era", Journal Of Small Business \& Enterprise Development, Vol. 17, No. 4, pp. 591-606. https://doi.org/10.1108/14626001011088741

40. Robuan, MRS; Jaén, I. and Liñán, F. (2017), "Promoting entrepreneurship in an unfavourable setting: a case study of a university programme in Malaysia", In: Santos, S. C., Caetano, A., Mitchell, C., Landström, H., \& Fayolle, A. (Ed), The emergence of entrepreneurial behaviour. UK: Edward Elgar Publishing, pp. 89111.

International Journal of Management and Applied Research, 2018, Vol. 5, No. 3 
41. Schön, D.A. (1983), The Reflective Practitioner: How Professionals Think in Action, New York: Basic Books.

42. Schultz, P. L., \& Quinn, A. S. (2014), "Lights, Camera, Action! Learning about Management with Student-Produced Video Assignments", Journal Of Management Education, Vol. 38, No. 2, pp. 234-258. https://doi.org/10.1177\%2F1052562913488371

43. Solomon, G. (2007), "An examination of entrepreneurship education in the United States", Journal of Small Business and Enterprise Development, Vol. 14, No. 2, pp. 168 - 182. https://doi.org/10.1108/14626000710746637

44. Systematic Educational Group International (2016), About SEGi, [Online] available from: http://www.segi.edu.my/en/node/3170 (Accessed 15 June 2016).

45. Szopa, A. (2015), Competitive Strategies for Academic Entrepreneurship: Commercialization of Research-Based Products: Commercialization of ResearchBased Products, United States of America: IGI Global.

46. Solomon, G. (2007), "An examination of entrepreneurship education in the United States", Journal of Small Business and Enterprise Development, Vol. 14, No. 2, pp. $168-182$.

47. Thompson, D. (2013), "Accelerating The Growth of The Next Generation of Innovators", Entrepreneurial Business Law Journal, Vol. 8, No. 2, pp. 379-391.

48. Timmons, J. (1999), The Entrepreneurial Process. In New Venture Creation: Entrepreneurship for the 21st Century, $5^{\text {th }}$ Edition, McGraw Hill

49. Van Manen, M. (2014). Phenomenology of Practice, California: Left Coast Press.

50. Yao S. C. (2003), "After The Malay dilemma: The Modern Malay subject and cultural logics of 'national cosmopolitanism' in Malaysia", Sojourn, Vol. 18, No. 2, pp. 201-29.

International Journal of Management and Applied Research, 2018, Vol. 5, No. 3 